\title{
The Influence of Service Quality, Price Perception, and Store Atmosphere on Repurchase Intention (Case Study at The Teras Atas Cafe Surabaya)
}

\author{
Rheza Septiani Pratiwi*, Santirianingrum Soebandi, \& I.G.A Aju Nitya Dharmani
}

Faculty of Economics anda Business, Narotama University Surabaya, Surabaya, Indonesia

\begin{abstract}
Repurchase intention is very influential in developing a business. Many factors affect repurchase intention, including service quality, perception price, and store atmosphere. The purpose of this study was to determine how the influence of service quality, perception price, and store atmosphere both simultaneously and partially affect on repurchase intention. The data was collected using a questionnaire. The research method uses as many random samples of 281 people. The analysis method using SPSS 18 . The results of this study indicate that the independent variables simultaneously influence the dependent variable. This research evidenced from the significance value of $<0,001$ or $<0,05$ and the $F_{\text {calculation }}=194.777$ while the $F_{\text {table }}$ obtained 2.66. Therefore $F_{\text {calculation }} 194.777>F_{\text {table }} 2,66$. But in partial variable, service quality is not significant into repurchase intention as in the results of testing showing $\mathrm{t}_{\text {calculation }}=0.961<\mathrm{t}_{\text {table }} 1.968$ with significance $0,337>0.05$.
\end{abstract}

Keywords: Service quality, perception price, store atmosphere, repurcahase intention.

\section{Introduction}

In this era, coffee shops is a comfortable place where visitors can enjoy a variety of their favorite coffees. Coffee shop was made with an interesting concept that makes visitors not only enjoy coffee but also can enjoy snacks such as potatoes, bread, or pasta with a warm atmosphere. As time goes by, in East Java, the number of cafes popping up in 2019 by $16 \%$ - $20 \%$ with urban lifestyle changes, especially among young people, according to (Zuhriyah, 2019). Haryono, head of the Indonesian cafe and restaurant businessman association (Apkrindo) said that the number of new entrepreneurs in the food and beverage sector continues to increase in Surabaya and Malang by 30 cafes. The businessman established business in food and beverages sector to achieve profit by attracting customers to make a repurchase intention.

Repurchase is a post-purchase action that is caused by a decision that is felt by consumers on products that have been purchased or consumed previously. If the product meets consumer expectations, then he will buy back and vice versa if it is not appropriate then they will react otherwise. Repurchase Intention is the intention to repurchase a product twice or more, both for the same and different products (Ardhanari, 2008).

From the results of an interview with the owner of the Teras Atas cafe in Surabaya, the thing that is lacking in this cafe is repurchase intention by customers. With the existence of repurchase intention, business actors can gain as much profit as possible. Various kinds of factors must be improved in order to re-purchase, among them is by increasing service quality. This will be considered for customers to intending a re-purchase. Realizing the existence of this kind of competition phenomenon requires businesses in East Java, especially in Surabaya, to continue innovate and upgrading their quality services to increase repurchase intention. According to Tjiptono (2005) service quality is an expected level of excellence where control over the level of excellence aims to meet customer needs. According

\footnotetext{
* Corresponding author.

E-mail address: rhezaseptiani07@gmail.com (Rheza Septiani Pratiwi)
} 
to previous research by Riko \& Laila ( 2013) states that service quality has a significant positive effect on repurchase intention through mediating customer satisfaction can be accepted. It can be seen based on the results of data analysis which shows that service quality has a significant positive effect on customer satisfaction and customer satisfaction has a significant positive effect on repurchase intention. Thus, it can be concluded that customer satisfaction is a mediator between service quality and repurchase intention .

The next factor that considered by customers to make purchases is perception price. It becomes a consideration for attracting customers to avoid losing from other competitors, with customers paying from the specified price, customers will also get the appropriate quality that is expected so that customers make repurchases intention . Price Perception is the price translated (encoded) by consumers. Thus, it can be said that price perception is closely related to customer perceptions of quality, value and other beliefs. Some studies suggest that price perception has a positive impact on customer satisfaction (Kaura 2012). Below is a price table taken from various coffee cafes in Surabaya

The results of this study support the findings of a number of previous studies by Wardan Sinaga ( 2016) good product quality and good perception price will be able to create the intention to repurchase. Satisfied customers will intend to repurchase the product again.

Another factor that concerns the customer is store atmosphere.With an attractive interior design it would attract customers to come. The store atmosphere arrangement in the Teras Atas Coffee was made as comfortable as possible for customers who mostly spend a long time to relax and talk with colleagues or friends. But this is still a challenge for business people to create a place that is truly comfortable. store atmosphere according to Kotler (2013) is the atmosphere of each outlet has a physical layout that makes it easy or difficult to get around in it. Store Atmosphere on purchasing intention examined by Nofiawaty \& Yuliandi ( 2014) shows that Store Atmosphere has a positive effect on consumer purchasing intention. This is contrary to the results of research conducted by Sandi Wicaksono, showing that store atmosphere has no effect on consumer buying interest.

From these phenomena it can be concluded that not every empirical event is in accordance with existing theories. This is reinforced by the existence of a research gap in previous research. The various studies above show a different effect from the store atmosphere variable which is seen to influence buying interest

\section{Literature review}

\subsection{Service Quality (X1)}

Parasuraman (1998) stated that Service Quality is a match between the expectations and desires of customers of Teras Atas Cafe Surabaya.

Indicators that affect Service Quality according to Parasuraman (1998)
a. Tangible (physical evidence )
b. Reliability
c. Responsiviness
d. Assurance
e. Emphaty

\subsection{Perception Price (X2)}

Stanton (1998) states Pe rception Price is the amount of money that is determined to acquire products and services on The Teras Atas Cafe Surabaya.

Indicators that affect Price Perception According to Stanton (1998)
a. Affordability of prices,
b. Price competitiveness,
c. Price match with product quality,
d. Price match with product benefits. 


\subsection{Store Atmosphere (X3)}

Husain \& Ali ( 2015) stated that store atmosphere has a big impact on the emotions and satisfaction of Teras Atas Cafe Surabaya.

Indicators that influence store atmosphere Husain \& Ali ( 2015) :
a. Hygiene (Cleanliness )
b. Music
c. Aroma ( Scent)
d. Temperature
e. Lighting
f. Color
g. Display or Layout

\subsection{Repurchase Intention $(Y)$}

Engel et al. (2001) state that repurchase intention reflects the hope of repurchasing products and services performed by Teras Atas Cafe Surabaya customers.

Indicators influencing Repurchase Intention according to Ferdinand (2002):
a. Product reviews by customer
b. Recommendation by customers to other
c. Desire to visit or buy back .

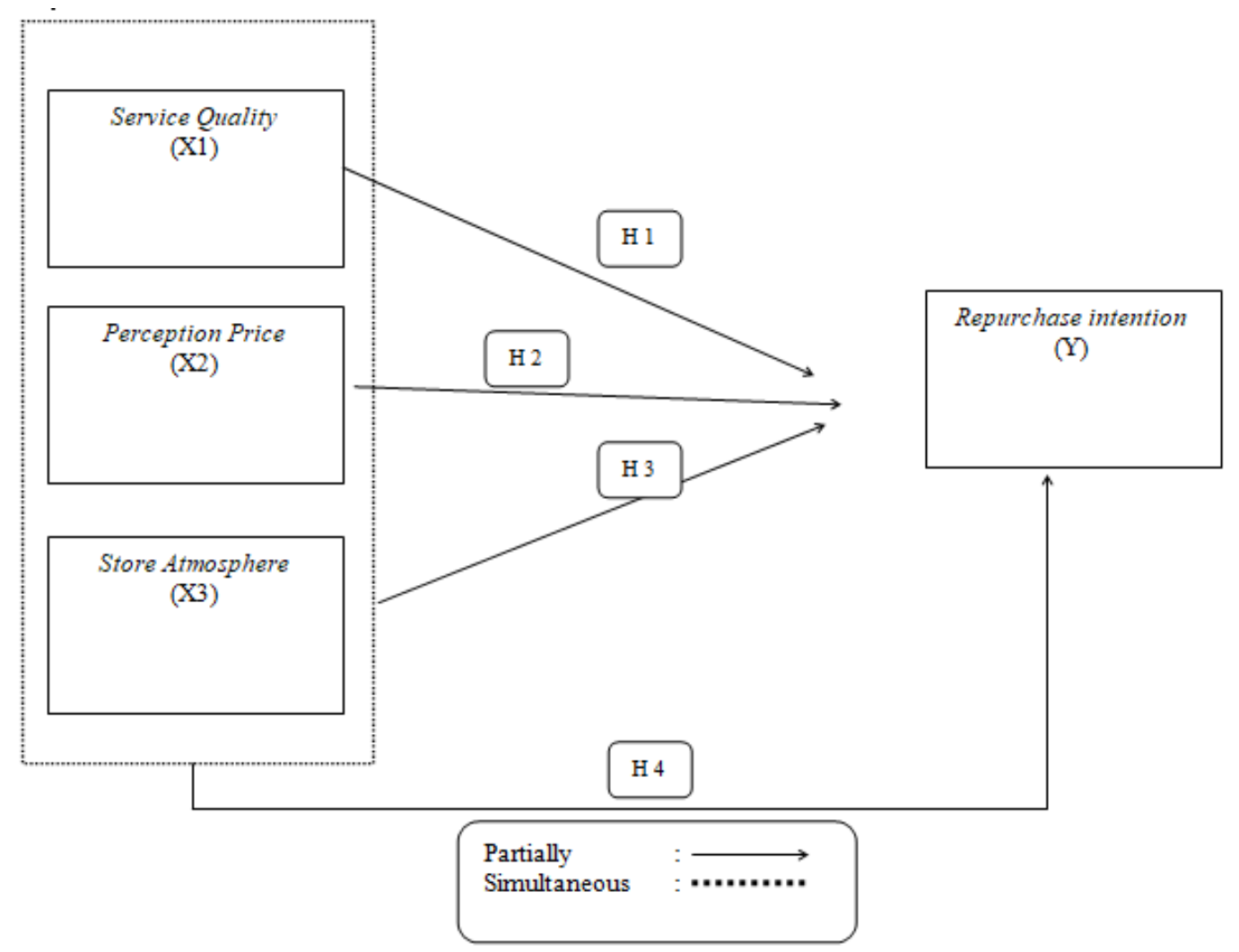

Fig. 1 Framework of Think 
Based on literature studies that have been conducted by researchers, both studies and refering to previous research. Then the researchers formulated several research hypotheses:

H1 : Does service quality (X1) have a significant effect on repurchase intention (Y) at The Teras Atas Cafe in Surabaya?

H2 : Does perception price (X2) have a significant effect on repurchase intention (Y) at The Teras Atas Cafe in Surabaya?

H3 : Does StoreAtmosphere (X3) have a significant effect on repurchase intention Y at The Teras Atas Cafe in Surabaya?

H4 : Is there a significant influence simultaneously on service quality, perception price, and Store Atmosphere on repurchase intention at The Teras Atas Cafe in Surabaya?

\section{Research methodology}

\section{Data analysis technique}

The research method uses a random sample of 281 people. The analytical method uses SPSS version 18. By using quantitative methods with the object of research is Teras Atas Cafe, sample of this research is on the Teras Atas visitors who had visited previously. Analysis technique of data using multiple linear analysis with using test validity, multicollinear, heteroskedacity using correlation $\mathrm{F}$ test and $\mathrm{T}$ test

\section{Results and discussion}

\subsection{Validity and Reliability Test}

Data processing used in this research uses version 18.0, with the type of data obtained by being transformed from ordinal to interval using the Method of Successive Intervel. To facilitate data acquisition in order to explain the results of respondents from the variables that will be examined.

Table 1. Test Validity

\begin{tabular}{ccccc}
\hline No. & Indicator / Variable & Correlation & r Table & Information \\
\hline & Service Quality & & & \\
1 & X1.1 & 0903 & 0.1170 & Valid \\
2 & X1.2 & 0.924 & 0.1170 & Valid \\
3 & X1.3 & 0.936 & 0.1170 & Valid \\
4 & X1.4 & 0.921 & 0.1170 & Valid \\
5 & X1.5 & & & \\
& Perception Price & & & \\
1 & X2.1 & 0903 & 0.1170 & Valid \\
2 & X2.2 & 0.924 & 0.1170 & Valid \\
3 & X2.3 & 0.936 & 0.1170 & Valid \\
4 & X2.4 & 0.921 & 0.1170 & Valid \\
& Store Atmosphere & & & \\
1 & X3.1 & 0.881 & 0.1170 & Valid \\
2 & X3.2 & 0.887 & 0.1170 & Valid \\
3 & X3.3 & 0907 & 0.1170 & Valid \\
4 & X3.4 & 0.912 & 0.1170 & Valid \\
5 & X3.5 & 0907 & 0.1170 & Valid \\
\hline
\end{tabular}




\begin{tabular}{ccccc}
\hline No. & Indicator / Variable & Correlation & r Table & Information \\
\hline 6 & X3.6 & 0.909 & 0.1170 & Valid \\
7 & X3.7 & 0.909 & 0.1170 & Valid \\
& Repurchase Intention & & & \\
1 & Y.1 & 0.938 & 0.1170 & Valid \\
2 & Y.2 & 0.945 & 0.1170 & Valid \\
3 & Y.3 & 0.933 & 0.1170 & Valid \\
\hline
\end{tabular}

Based on the results of the validity test according to the table above, for all dimensions states that of the 19 item questions, there are none invalid items. Thus the number of valid items will be used as a tool to collect 19 research questions.

Table 2: Reliability Test

Reliability Statistics

\begin{tabular}{cc}
\hline Cronbach's Alpha & N of Items \\
0.980 & 19 \\
\hline
\end{tabular}

Based on the table above on the reliability test above, the data of this study have a Cronbach's alpha value of 0.980 and more than 0.5 , so the data is declared reliable .

\subsection{Multiple Linear Regression Analysis}

Multiple linear regression analysis in this study is used to find out the relationship on service quality $\left(\mathrm{X}_{1}\right)$, perception price $\left(\mathrm{X}_{2}\right)$, Store Atmosphere $\left(\mathrm{X}_{3}\right)$ as independent variables on Repurchase Intention $(\mathrm{Y})$ on this variable is the dependent variable. The multiple linear regression equation that has been obtained from the results of data that has been processed in the SPSS program.

Table 3 Coefficient of Determination Test

Summary Model ${ }^{\mathrm{b}}$

\begin{tabular}{|c|c|c|c|c|c|}
\hline \multirow{2}{*}{ Model } & \multirow[b]{2}{*}{$\mathrm{R}$} & \multirow[b]{2}{*}{ R Square } & \multicolumn{3}{|c|}{ Std. Error of the } \\
\hline & & & Adjusted R Square & Estimate & Durbin-Watson \\
\hline dimension01 & $0.824^{\mathrm{a}}$ & 0.678 & 0.675 & 1.716 & 1.591 \\
\hline
\end{tabular}

a. Predictors: (Constant), Store Atmosphere, Service Quality, Perception Price

b. Dependent Variable: Repurchase Intention

\subsection{Hypothesis testing}

\subsubsection{T-test}

T-test is used to test the significance of the constants of each variable independently, whether the variable service quality $\left(\mathrm{X}_{1}\right)$, perception price $\left(\mathrm{X}_{2}\right)$, store atmosphere $\left(\mathrm{X}_{3}\right)$ truly influenced partially (separately) on the dependent variable, repurchase intention $(\mathrm{Y})$. Criteria:

1) If the $t$ count $>t$ table, or the level of significance $<0.05$ means that each independent variable partially and significantly influence to the dependent variable.

2) If $t$ count $<\mathrm{t}$ table, or the level of significance $>0.05$ means that each independent variable didn't partially and significantly influence to the dependent variable. 
Table 4: Test T

\begin{tabular}{|c|c|c|c|c|c|c|c|c|}
\hline \multicolumn{9}{|c|}{ Coefficients $^{a}$} \\
\hline \multirow[t]{2}{*}{$\mathrm{Moc}$} & & \multicolumn{2}{|c|}{$\begin{array}{l}\text { Unstandardized } \\
\text { Coefficients }\end{array}$} & $\begin{array}{l}\text { Standardized } \\
\text { Coefficients }\end{array}$ & \multirow[b]{2}{*}{$\mathrm{t}$} & \multirow[b]{2}{*}{ Sig. } & \multicolumn{2}{|c|}{ Collinearity Statistics } \\
\hline & & $\mathrm{B}$ & Std. Error & Beta & & & Tolerance & VIF \\
\hline \multirow[t]{4}{*}{1} & (Constant) & 0.906 & 0.451 & & 2.009 & 0.046 & & \\
\hline & Service Quality & 0.047 & 0.048 & 0.072 & 0.961 & 0.337 & 0.206 & 4.850 \\
\hline & Perception Price & 0.298 & 0.061 & 0.370 & 4.912 & 0.000 & 0.204 & 4.898 \\
\hline & Store Atmosphere & 0.188 & 0.038 & 0.413 & 5.018 & 0.000 & 0.171 & 5.835 \\
\hline
\end{tabular}

${ }^{a}$ Dependent Variable: Repurchase Intention

Based on the table above, noted that $\mathrm{t}$-value variable of service quality $\left(\mathrm{X}_{1}\right)$ calculated 0.961 , perception price $\left(\mathrm{X}_{2}\right)$ 4.912 and store atmosphere (X3) 5.018 .

1. Testing the effect of service quality on repurchase intention

The test results obtained $t$ value for the service quality variable to repurchase intention shows the value of $t_{\text {count }}=$ $0.961<$ from $\mathrm{t}_{\text {table }} 1.968$ with a significance of $0.337>0.05$ which means insignificant. Thus partially service quality is not positively gives significant effect on repurchase intention at Teras Atas Cafe.

2. Testing the effect of perception price on repurchase intention

The test results obtained the value of $\mathrm{t}$ value for brand image variables to the re-purchase intention shows the value of $\mathrm{t}_{\text {count }}=4.912>$ from $\mathrm{t}_{\text {table }} 1.968$ with significance level $<0.05$ which means significant. Thus partially perception price positively gives significant effect on repurchase intention at Teras Atas Cafe.

3. Testing the effect of store atmosphere on repurchase intention

The test results obtained $\mathrm{t}$ value for a variable store atmosphere to re-purchase intention shows the value $\mathrm{t}_{\text {count }}=5,018>\mathrm{t}_{\text {table }} 1,968$ with significance level $<0.05$ which means significant. Thus partially store atmosphere positively gives significant effect on repurchase intention at Teras Atas Cafe.

\subsubsection{F Test (Simultaneous)}

According to Ghozali (2005) the F test is used to test the level of significance of the influence of the independent variables on the dependent variable simultaneously. By using the $\mathrm{F}$ test that is to compare values with values. If the probability value $<0,05$ then the $\mathrm{F}$ test can be used to predict the effect of the independent variable on the dependent variable simultaneously. The significance of this influence can be estimated as a criterion of the dependent variable.

1) If or significant level $<0.05$ then the independent variable simultaneously influences the dependent variable.

2) If or significant level $>0,05$ then the independent variable simultaneously has no effect on the dependent variable. 
Table 5. Test $\mathrm{F}$

\begin{tabular}{cccccc}
\multicolumn{7}{c}{ ANOVA $^{\mathbf{b}}$} \\
Model & Sum of Squares & Df & Mean Square & F & Sig. \\
\hline Regression & 1720.743 & 3 & 573.581 & 194.777 & $<0.001^{a}$ \\
Residual & 815.712 & 277 & 2.945 & & \\
Total & 2536.456 & 280 & & & \\
\hline
\end{tabular}

a. Predictors: (Constant), Store Atmosphere, Service Quality, Perception Price

According to the table above is known that the obtained $\mathrm{F}_{\text {count }}=194.777$ while the value of $\mathrm{F}_{\text {table }}$ obtained by 2,66 . Therefore $F_{\text {count }}$ is $194.777>F_{\text {table }}$ is 2,66 . And significant value $<0,001<0,05$ so it can be concluded service quality (X1), perception price (X2), and store atmosphere (X3) are simultaneously positive and significant effect on repurchase intention (Y) at Teras Atas Cafe.

\subsection{Classical Assumption Test}

\subsubsection{Normality test}

The normality test aims to test whether in the regression model the confounding or residual variables have a normal distribution. As it is known that the $\mathrm{t}$ and $\mathrm{F}$ test assumes that the residual value follows the normal distribution. There are two ways to detect whether residuals are normally distributed or not, namely by analyzing the graph and the statistical test Ghozali (2005). In principle, normality can be detected by looking at the spread of data (points) on the diagonal axis of the graph or by looking at the histogram of its dual regression. The basis for decision making includes Ghozali (2005):

1) If the data (point) spreads around the diagonal line and follows the direction of the diagonal line or the graph shows a normal distribution pattern, then the regression model meets the normality assumption.

2) If the data (point) spreads far from the diagonal and or does not follow the direction of the diagonal line or the graph does not show a normal distribution pattern, then the regression model does not meet the assumption of normality.

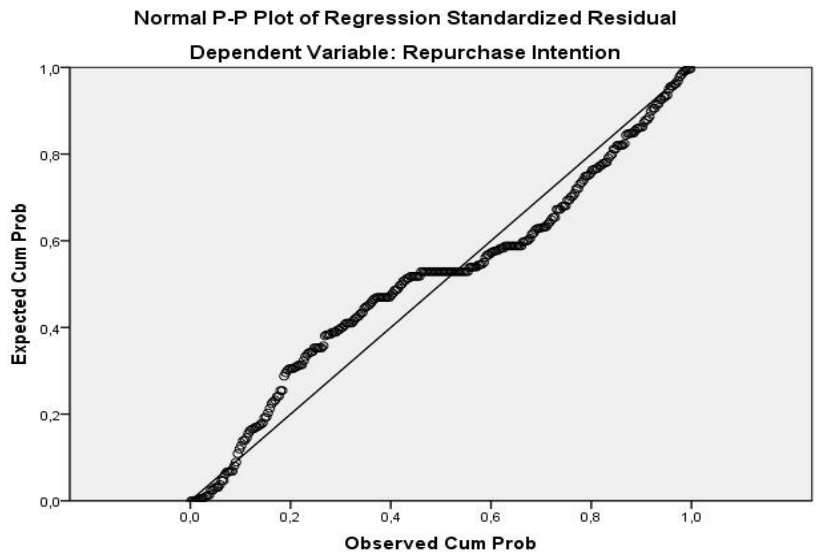

Fig. 2 Normality Test Results

Source: SPSS Output Data (2020) 
In the figure 2, it can be seen that the standardized normal plot of regression plot shows a normal graph pattern. This can be seen from the points that spread around the diagonal lines and diagonal lines from the lower left to the upper right . Then it can be concluded that the regression model is feasible because it meets the assumption of normality.

\subsubsection{Multicollinearity Test}

Multicollinearity test aims to test whether in the regression model was found a correlation between independent variables. If multicollinearity is found, the variable regression coefficient is indeterminate and the error becomes infinite Ghozali (2005). The multicollinearity test in this study can be seen in table 6 .

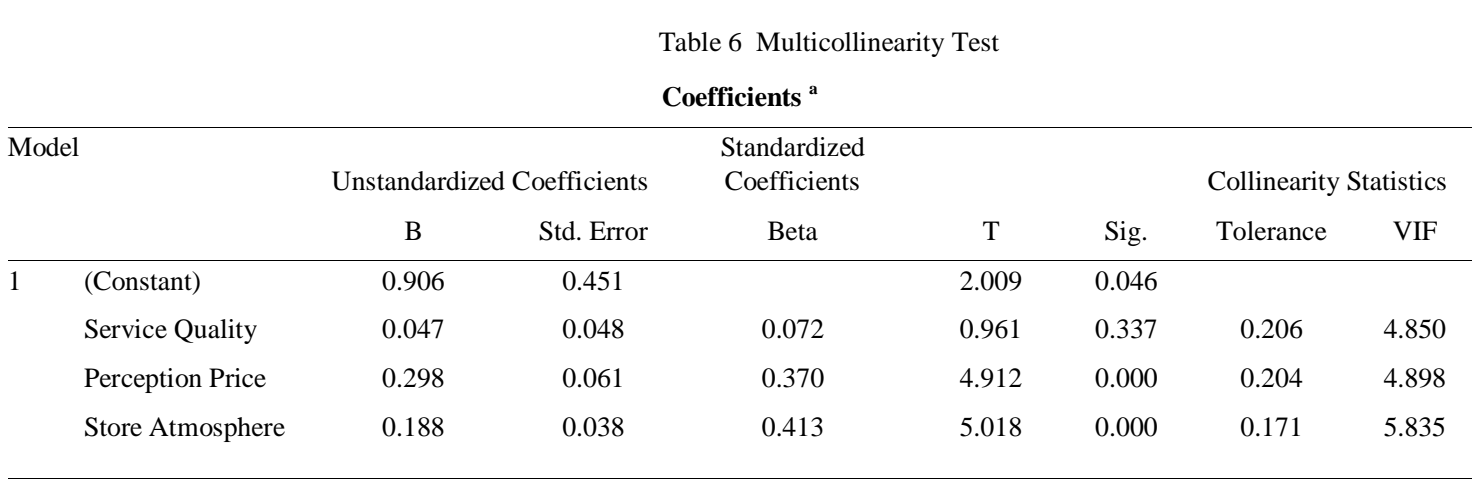

a. Dependent Variable: Repurchase Intention

Based on the table 6, it can be seen that the regression model does not experience multicollinearity disorder. This can be seen in the tolerance value of each independent variable greater than 0.1. VIF calculation results also show that the VIF value of each independent variable is less than 10. So it can be concluded that there is no multicollinearity between independent variables in the regression model

\subsubsection{Heteroscedasticity test}

Heteroscedasticity test aims to test whether in the regression model there is an unequal variance from the residuals of one observation to another (Ghozali, 2005). A good regression model is homoscedasticity or heteroscedasticity does not occur. To measure heteroscedasisity can be determined by observing scatterplot charts (fig. 3). Homoscedasticity occurs when the scatterplots of data processing results between $Z_{\text {pred }}$ and $S_{\text {resid }}$ spread below or above the original point (number 0) on the $\mathrm{Y}$ axis and do not have a regular pattern. Heteroscedasticity occurs when the scatterplot points have a regular pattern (Sunyoto, 2001).

Based on the figure 3, the scatter plot shows the points spread evenly so that it meets the assumption of heterokedasticity.

\section{Conclusions}

Based on the discussion of the results of study, it can be concluded that:

1) Service quality $(\mathrm{X} 1)$ does not significantly influence repurchase intention $(\mathrm{Y})$. Where the value of $\mathrm{t}_{\text {count }}=$ $0,961<$ from $t_{\text {table }} 1.968$ with a significance of $0,337>0,05$ means that service quality does not affect the repurchase intention on Teras Atas Cafe Customers.

2) Perception price (X2) effect significantly late to repurchase intention (Y). Where shows the value of $\mathrm{t}_{\text {count }}=4.912>$ from $\mathrm{t}_{\text {table }} 1,968$ with a significance of $0,000<0,05$ which means significant. In this case the perception price has a significant effect to the repurchase intention on Teras Atas Cafe Customers. 
3) Store atmosphre (X3) partially to the repurchase Intention (Y). Where the value of $t_{\text {count }}=5,018>$ from $\mathrm{t}_{\text {table }} 1,968$ with a significance of $0,000<0,05$ which means significant . In this case the store atmosphere has a significant effect to the repurchase intention on Teras Atas Cafe Customers.

4) Variable service quality (X1) does not significantly affect repurchase intention while perception price (X2) and store atmosphere (X3) influence simultaneously influenced to the repurchase Intention (Y) with significant value less than 0.05 is equal to 0.000 .

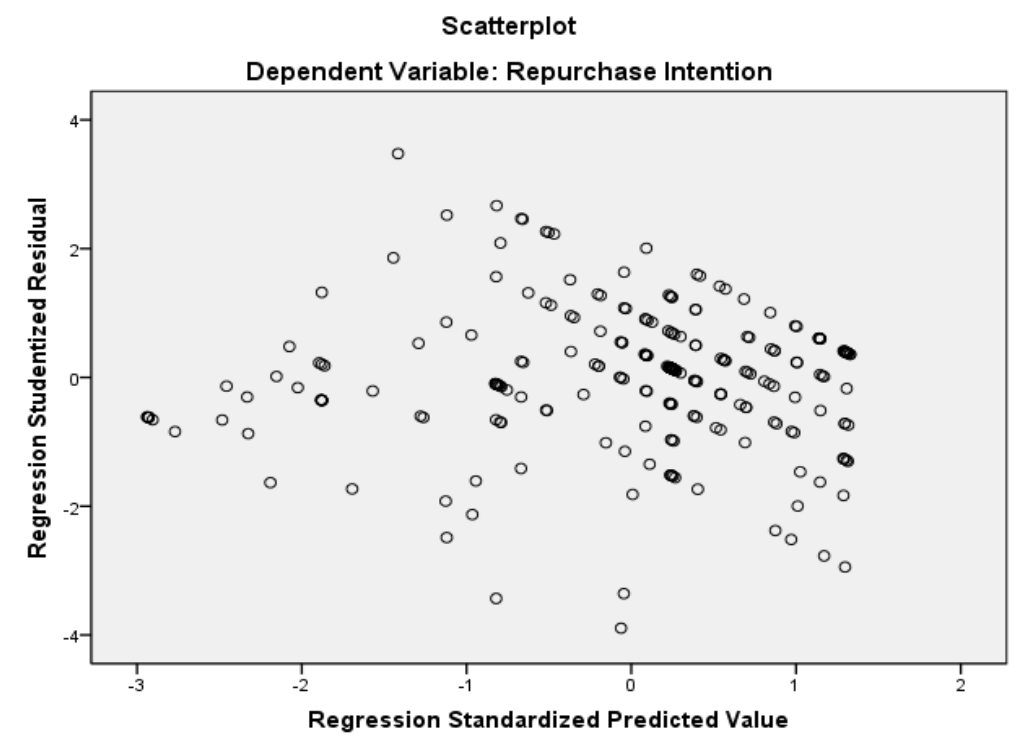

Fig. 3 Heteroscedasticity Test

\section{References}

Ardhanari, M. (2008). Customer Satisfaction Pengaruhnya Terhadap Brand Preference Dan Repurchase Intention Private Brand. Jurnal Riset Ekonomi dan Bisnis, 8(2), 58-69.

Engel, J. F., Roger D, B., \& Paul W, W. (1995). Consumen Behaviour. In Eight Edition (P. 283). Orlando: The Dryden Press.

Ferdinand. (2002). Structural equation modelling dalam penelitian manajamen. Seri pustaka kunci 03/ BP UNDIP.

Ghozali. (2005). Aplikasi Analisis Multivariate dengan Program SPSS. semarang: UNDIP.

Husain, R., \& Ali, M. (2015). Effect of store atmosphere on consummer purchase intention. canadian center of science and education.

Kaura. (2012). perceived prices, price fairness and customer satisfaction. Pacific Business Review International.

Kotler. (2013). Manajemen Pemasaran. Jakarta: Erlangga.

Nofiawaty, \& yuliandi. (2014). Pengaruh Store Atmospher Terhadap Keputusan Pembelian Konsumen Pada Outlet Nyesnyes Palembang.Jurnal Manajamen Bisnis Sriwijaya, 12(1).

Parasuraman (1998). Servqual: A Multiple Item Skale For Measuring Consumer Perception of Service. Journal of Retailing. 
Sinaga. (2016). AnalisisPengaruh Citra Merek, Kualitas Produk danPersepsi Harga Terhadap Loyalitas KonsumenProduk Pasta Gigi Pepsodent. Global, hal 1-11.

Stanton. (1998). Prinsip Pemasaran. Edisi Ketujuh. Jakarta: Erlangga.

Tjiptono, F. (2005). Service, Quality \& Satisfaction. Yogyakarta: Andi Offset.

Zuhriyah, D. A. (2019, Agustus 22). bisnis.com. Retrieved Oktober 14, 2019, from bisnis.com: http://www.bisnis.com 